\title{
RNAi Technique to Control Cotton Leaf Curl Disease (CLCUD)
}

Rana Khalid Iqbal ${ }^{1}$,

Muhammad Saad Bhutta ${ }^{1}$,

Kinza Mushtaq ${ }^{1}$, Samina

Hassan $^{1}$ \& Aqsa Taram ${ }^{1}$

${ }^{1}$ Institute of Molecular Biology \& Biotechnology, Bahauddin Zakariya University, Multan-60880, Pakistan

\section{Corresponding Author}

Author Email:

Khalid.iqbal@bzu.edu.pk

DOI: $10.38177 / A J B S R .2020 .2204$

\section{Introduction}

Cotton is one of the major cash crops of the world (Briddon 2003). More than 100 countries in the world grow cotton. Cotton is susceptible to various

\begin{abstract}
Cotton is the major cash crop of South Asian countries. Due to its large cultivation, it is susceptible to various fungal, bacterial and viral diseases. Out of viral diseases, Cotton leaf curl virus (CLCUV) is the most devastating viral disease of cotton. It is caused by begomovirus of family geminiviridae and spread by ubiquitous whitefly (Bemisia tabaci). Due to the vast destruction caused by this virus in 1992 and 2001, farmers and scientists tried to tackle this disease through various techniques and methodologies. All these techniques are not fruitful because this virus is not easy to handle. This is because of the structure and environmental conditions in which virus survives. RNAi technique is the natural defense mechanism against viruses in plants, animals, and fungus. Biotechnologists used this technique for their own benefit. They manipulate the viral genome through this technique and made the plant resistant to disease. They diminish the expression of viral genome by DNA methylation and by post-transcriptional gene silencing (PTGS). In DNA methylation, a methyl group is attached to a gene of viral coding protein and restricts its transcription. In PTGS, dSRNA molecule is produced by the cell itself or can be inserted in the cell from outside. This dsRNA form dicer with microRNA and cut the MRNA of virus which is to be translated for disease-causing infectious protein. Thus, by using the RNAi technique, the viral genome of begomovirus is degraded and its expression is suppressed.
\end{abstract}

Keywords: Begomovirus, Betasatellite, Post-Transcriptional Gene Silencing (PTGS), Whitefly.

fungal, bacterial, parasitical and even viral diseases (Sun and Yuan 2017). In Pakistan, cotton accounts for $1.5 \%$ of total GDP (GoP 2010). According to the US department of agriculture, annual cotton production of Pakistan in 2018 is 8000 (unit, $1000480 \mathrm{lb}$. Bales), which decreased from 10600 in 2014. The decrease in yield is due to various factors, including many diseases and numerous other factors like political, lack of knowledge of farmers etc.

One of the most devastating viral diseases of cotton, which has affected the cotton adversely, is Cotton leaf curl disease (Hashmi et al. 2011). It is caused by a specie begomovirus of family geminiviridae and spread through the ubiquitous whitefly. The major attack of the virus is in southern Asia because this region provides the best condition for growth of the best cotton. In Pakistan, it first appeared in 1967 on few plants in Multan and in 1992-93, caused a decline in production down to 9.05 million bales and during 1993-94, to 8.04 million. That was a significant decrease in cotton production in Pakistan (Farooq et al. 2014). During the late 1990s, the resistant variety was introduced in the market and 
diminishes the disease to great extent (Rahman et al. 2017). Then again in 2001, the resistant variety was observed to having diseased symptoms again. This signaled the start of a second epidemic. (Amrao et al. 2010).

There are many conventional methods to control the virus including late sowing, seed poisoning etc. but all these methods are useless as virus emerges with the new strain. So molecular techniques should be used to circumvent the disease. One of these techniques is the RNAi technique.

\section{What is the cotton leaf curl virus?}

Cotton leaf curl disease is caused by the cotton leaf curl virus. The disease induces upward curling of leaves, vein thickening, dark green coloration of leaves, small leaf-like appearance under the leaf, leaf enation, plant become a dwarf, decrease fiber length, bowl size. Fiber length also decreases (Sattar et al. 2013).

Cotton leaf curl virus (CLCuV) or cotton leaf curl disease (CLCUD) is caused by a complex of begomoviruses in association with satellite molecules i.e. Alpha and Beta satellite (Iqbal et al. 2016). Satellite viruses are those which have small sequence of nucleotide that depend on their helper virus for most of the function but helper virus is not depend upon its satellite molecule for anything (Krupovic and Cvirkaite-krupovic 2011). Of these two satellites of begomovirus, betasatellite has more role in appearance of symptoms of the disease (as it encodes for suppressor protein BC1 (Mubin et al. 2010)) as compared to Alphasatellites. The protein encoded by betasatellite, i.e. BC1, is a suppressor of host defense (Hussain et al. 2007), a pathogenicity

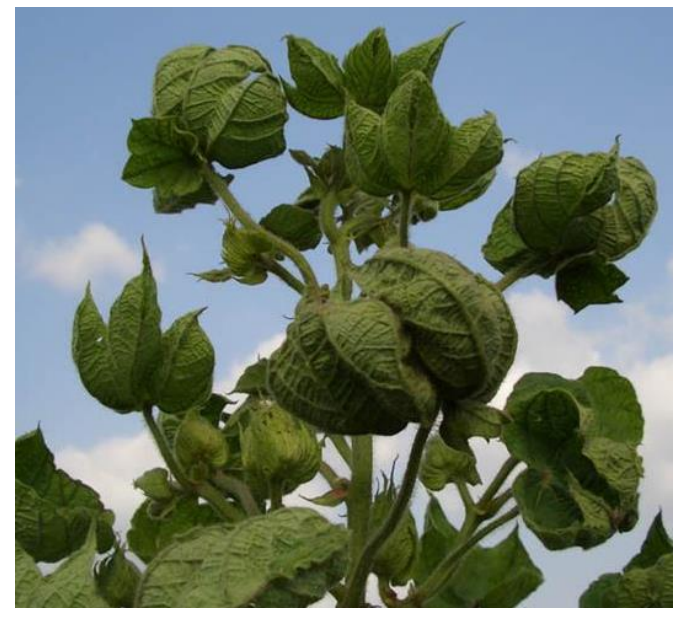
determinant (Saeed et al. 2007). CLCUD is transmitted by begomovirus of family geminiviridae. Family geminiviridae include 360 species with 9 genera. CLCuD associated begomovirus is transmitted by ubiquitous whitefly Bemisia tabaci (Iqbal et al. 2016). The genomes of whitefly-transmitted geminiviruses consist of two molecules (Mansoor et al. 2008), DNA-A and DNA-B (Monga et al. 2011), or of one DNA-A-like molecule, of circular single-stranded DNA (Liu et al. 1998). A small number of begomoviruses have a monopartite DNA genome that resembles the DNA A of bipartite begomoviruses. This DNA carries all necessary gene functions for replication and pathogenesis (Saeed et al. 2007). No evidence is found about cotton leaf curl virus isolates possess a DNA-B, for simplicity we refer the DNA-A-like molecules as DNA-A (Liu et al. 1998). 


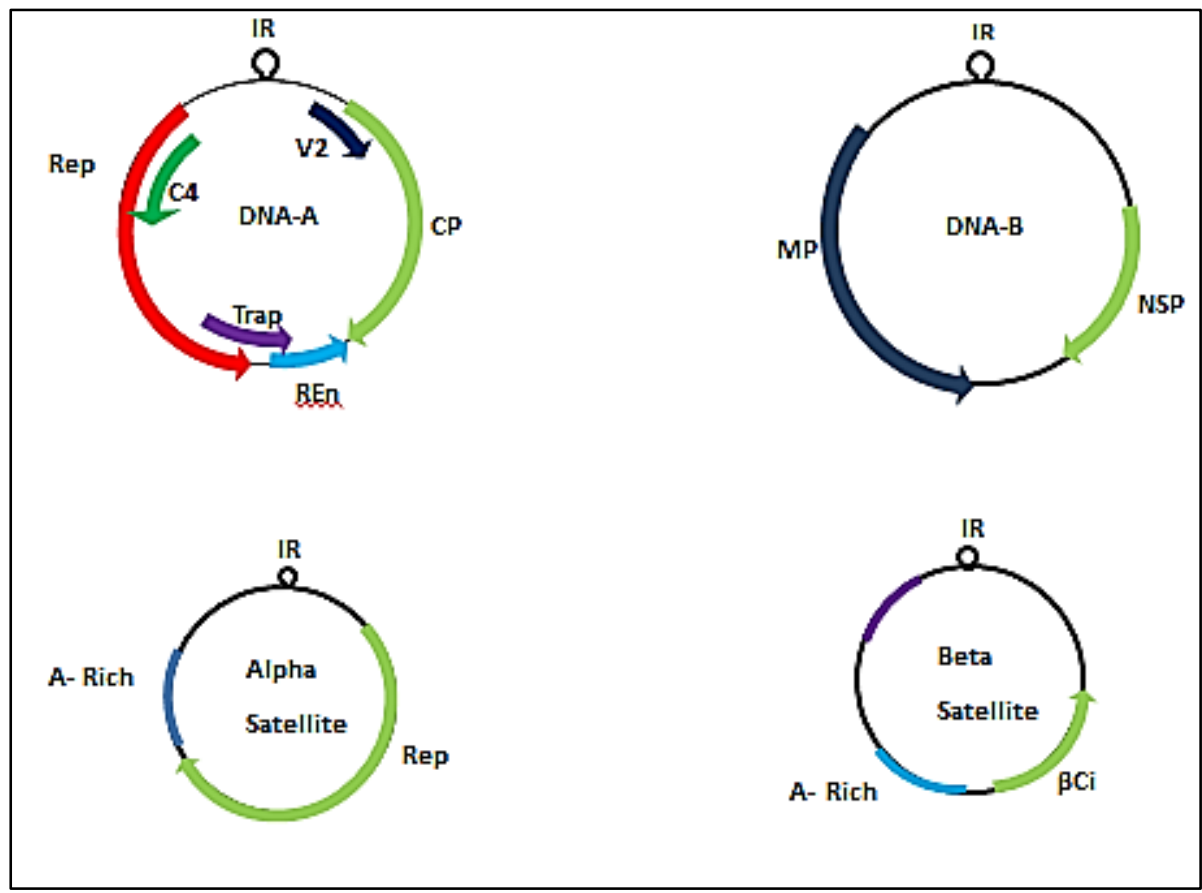

Fig 2. Begomovirus mostly have bipartite genome (DNA-A and DNA-B) but sometimes it also exhibit monopartite genome (DNA-A like genome). Begomovirus is associated with two satellite molecules (Alpha satellite and beta satellite). These satellites play role in disease transmission in host cell.

\section{Available methods to tackle the disease}

Management of CLCuD includes various ways inclusive of:

\section{A. Conventional methods}

1. change in sowing time (changing climate scenario, cotton varieties either susceptible are sown early can escape from virus and whitefly but the resistant one could be susceptible in late sowing which is the cause of ambiguity between susceptible and resistant (Farooq et al. 2014)),2. Crop nutrition (low supply of $K$ decreased the growth, but it also increased the severity of disease incidence in the plant. Increase in disease incidence is possibly associated with lower photosynthetic pigments, lower rates of photosynthesis, and lower $\mathrm{K}$ and $\mathrm{N}$ use efficiency and low accumulation of $\mathrm{Mg} 2+$ in the leaves (Zafar and Athar 2013)), 3. Cultural practices, 4. Vector control (Rahman et al. 2017), 5. Buffer crops and 6. Systemic poisoning of cotton seed by seed treatment 7. Eradicating weeds (Smalling et al. 2013) (Saxena and Tiwari 2017) (Malik et al. 2016) (X et al. 2012) will make the cotton crop relatively safe. But all these conventional methods are not successful to control this disease as all these are short term remedies (Vyas et al. 2017) (Follett 2017) (Basit et al. 2013). Introducing resistant variety is not helpful so far (Sattar et al. 2013) because a new viral strain emerges and causes destruction of crop. 


\section{B. Molecular techniques}

With the emergence of biotechnology, various techniques and methods introduced to manipulate the DNA and in result to manipulate the protein which is encoded by specific sequence on that DNA. These techniques include various molecular biology techniques, genetic engineering, CRISPR cas9, RNAi; moreover various markers have been developed to identify the pathogenic gene and replacing it with a beneficial gene through gene therapy technique. Biotechnologists introduce the technique of gene silencing (RNAi), which eliminate or degrade the mRNA that translates for that viral protein or in some cases, the viral coding gene (Pooggin et al. 2003). In this review article, we discuss that how we control this epidemic disease by the use of RNA interface (RNAi) technique, in which mRNA transcribed by DNA molecule is degraded or manipulated to stop translation of the viral protein.

\section{Difficulties in controlling the disease}

The disease epidemiology is changed by abiotic factors especially temperature and plant age (Farooq et al. 2011). As this disease is transmitted by whitefly, using insecticidal may seem appropriate. But when whitefly is seen in the fields, it is possible that flies have already transmitted the virus to plant (Khan et al. 2015). Whitefly is also the vector of various viral diseases. So the various viral genomes combine to form new strain which is uncontrollable. A new strain of CLCuV has emerged (Saleem et al. 2016) which is the combination of Multan strain and khokhran strain. That new strain is called Burewala strain and cause great cotton disaster/catastroph in 2001-02 in Pakistan. Various conventional methods are used to control the disease like late sowing, seed treatment etc. All these methods are successful to some extent but cannot control the virus completely. Introducing resistance species is also not successful so far because resistance broke and plant again become susceptible to disease (Singh 2014). According to an Indian researcher, the disease is also difficult to control because every farmer does not take the precautionary measures. If a single farmer take the basic precautionary measures, and other does not, the disease cannot be controlled because whitefly will attack from neighboring farmer's field.

\section{RNAi technique, why we use it?}

RNA interference or RNAi technique is the method to control the gene expression. It is also the basic defensive technique (Voinnet O. 2001) in plants, animals, and fungi against viral attack (Belk 2014). By the advancement of science, the RNAi technique has begun in laboratories for desired purposes. It is also being used to make any cultivar virus-free. It is widely used for plants that cannot be made virus free by conventional methods. 


\section{Methods in RNAi technique}

RNAi technique diminishes the viral attack in two ways, one is by DNA methylation and other is by mRNA degradation or post-transcriptional gene silencing (PTGS) (Shepherd et al. 2009).

\section{DNA methylation}

In DNA methylation, a methyl group is attached to the DNA molecule (Schübeler 2015) which restricts the transcription of that specific portion of DNA (Du et al. 2015). DNA methylation is the epigenetic mark, i.e. it didn't alter the structure of DNA in generations (Jin et al. 2011). It is widely used for clinical treatments and as a tumor suppressor (Lopez-Serra and Esteller 2012). This technique is also very efficient for gene silencing, to suppress the effect of any gene in plants and animals (Law and Jacobsen 2010). Thus by using DNA methylation, one can suppress the effect of any unwanted nucleotide sequence (Law and Jacobsen 2010).

\section{Post-transcriptional gene silencing (PTGS)}

In mRNA degradation, post-transcriptional gene silencing (PTGS) is most common. In PTGS, viral mRNA is degraded. dsRNA molecule is inserted in the cell (Pusch et al. 2003).

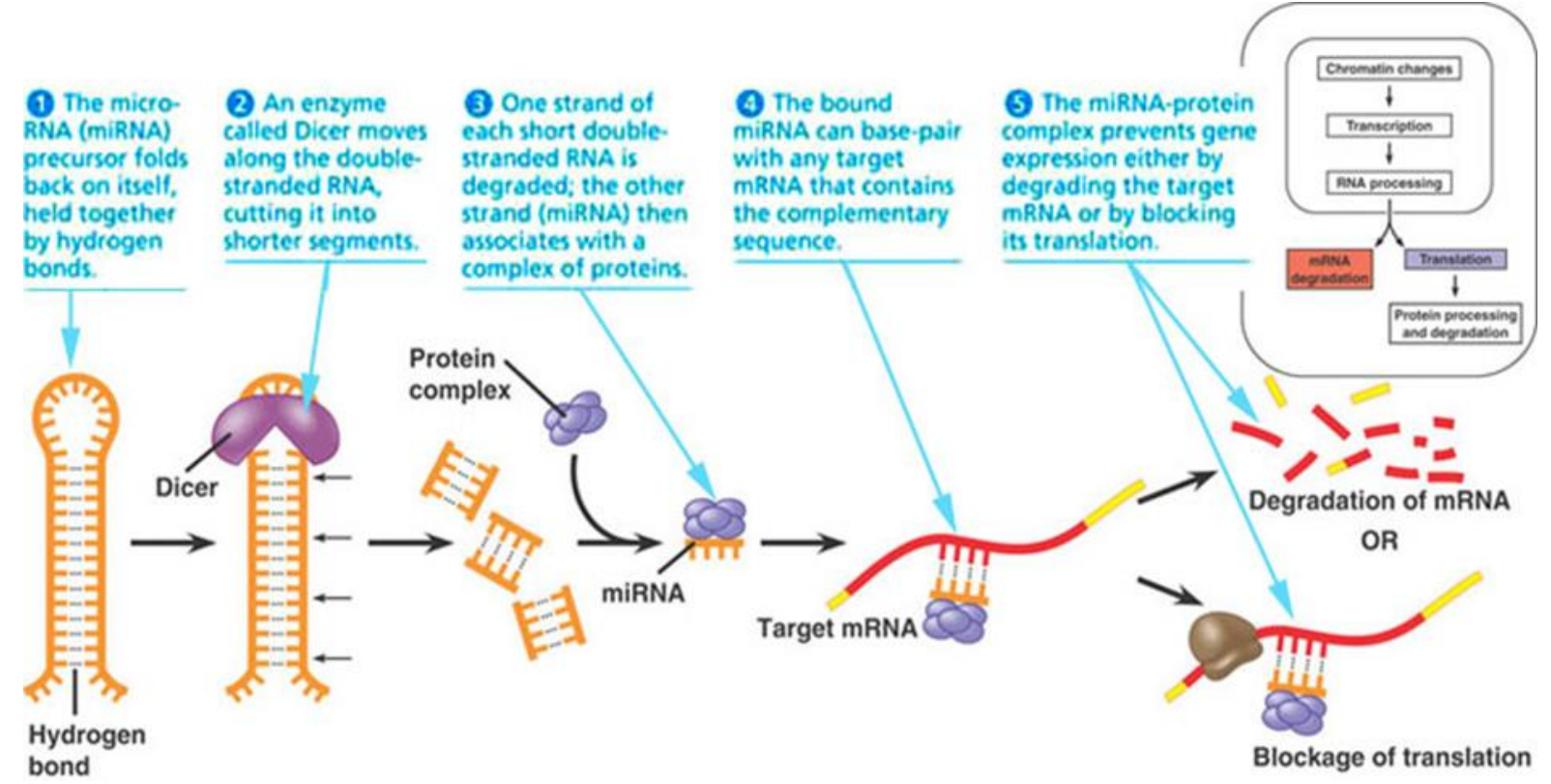

(Pusch et al. 2003) or produced by the cell itself as its normal mechanism. These dsRNA form complex with micro RNA which is also produced by the cell itself in the nucleus (Saeed et al. 2015). Micro RNA and dsRNA form complex and then cleaved into small RNA of almost 21 to $25 \mathrm{nt}$ in length (Shepherd et al. 2009). This small RNA then binds to argonaute protein which helps to convert dsRNA into ssRNA and moreover bind that ssRNA to the desired 
mRNA which is to be degraded (Höck and Meister 2008). That attachment of ssRNA with mRNA is precise because ssRNA contains the complementary sequence of that unwanted mRNA. Thus mRNA then cleaved into small fragments and thus their expression will be lost (Shepherd et al. 2009). By using the same PTGS technique, one can suppress the viral expression of begomovirus causing CLCUD. One can suppress this expression in both vector as well as in the plant. But relatively difficult in the plant because when whitefly is visualized in filed, it has already transmitted the virus to plants (Khan et al. 2015). By this method, one can also degrade the betasatellite, as it also plays a vital role in disease by suppressing the host defense mechanism. The protein encoded by beta satellite can also be altered by PTGS (Qazi et al. 2007).

\section{To which extent this method is successful}

RNAi technique is the natural defense mechanism in plant, animals, and fungi (Belk 2014). With the emergence of science, this technique has been using for various purposes, to express the desired gene. RNAi technique is used to control many viral diseases by degrading the viral genome in the host cell. Various viral diseases of geminivirus of various plants are treated through this technique. This includes Mungbean yellow mosaic virus-Vigna (MYMV-Vig) (Pooggin et al. 2003), African cassava mosaic virus (ACMV) (Bieńkowska and Umińska-Tytoń 2015), and various other plant species like tobacco (Pooggin and Hohn 2004). So RNAi technique is also used on the cotton plant to tackle CLCUD. Various methodologies and experiments are conducted on cotton plant and the resistant gene is made through RNAi technique, which helps plant in fighting begomovirus (Khatoon et al. 2016). But all these methods are successful to some extent but not completely. Viruses have very small genome size (Chemla and Smith 2012), their genome change abruptly and change according to the condition. So developing the virus resistant variety is not a good idea for long term use (Singh 2014). So, in addition to developing resistant variety, various other precautionary measures should be taken to develop the crop resistant to this disease. We cannot ignore conventional methods altogether, because they are also to some extent. So, biotechnologists and conventional breeders should work together to design the technique and methodologies to tackle the disease.

\section{Conclusion}

CLCuV is a bipartite virus associated with two satellite molecules alpha and beta satellite. Beta satellite plays an important role as it encodes for the host defense suppressor protein and various other disease-causing protein. Through RNAi technique, we can degrade the problem causing mRNA degradation through PTGS or methylation of that gene can also be 
done to diminish the expression of the viral protein. RNAi technique to control this disease is also not much beneficial so far as viral strain emerges rapidly. But still, it is most convenient and useful method, among gene silencing, to tackle the cotton leaf curl and virus and cotton leaf curl disease.

\section{References}

Amrao L, Amin I, Shahid MS, et al (2010) Cotton leaf curl disease in resistant cotton is associated with a single begomovirus that lacks an intact transcriptional activator protein. Virus Res 152:153-163. doi: 10.1016/j.virusres.2010.06.019

Basit M, Saeed S, Saleem MA, et al (2013) Detection of Resistance, Cross-Resistance, and Stability of Resistance to New Chemistry Insecticides in \&lt;I\&gt;Bemisia tabaci\&lt;/I\&gt; (Homoptera: Aleyrodidae). J Econ Entomol 106:1414-1422. doi: 10.1603/EC12414

Belk R (2014) Baulcombe_2004_RNA silencing in plants. 18:7-23.

Bieńkowska D, Umińska-Tytoń E (2015) The language creation of the city and its inhabitants in folklore texts of the city of Łódź. Stud Językoznawcze synchroniczne i diachroniczne aspekty badań Polszcz 14:43-55. doi: 10.18276/sj.2015.14-03

Briddon RW (2003) Cotton leaf curl disease, a multicomponent begomovirus complex. Mol Plant Pathol 4:427-434. doi: 10.1046/j.1364-3703.2003.00188.x

Chemla YR, Smith DE (2012) Single-molecule studies of viral DNA packaging. Adv Exp Med Biol 726:549-584. doi: 10.1007/978-1-4614-0980-9_24

Du J, Johnson LM, Jacobsen SE, Patel DJ (2015) DNA methylation pathways and their crosstalk with histone methylation. Nat Rev Mol Cell Biol 16:519-532. doi: $10.1038 / \mathrm{nrm} 4043$

Farooq A, Farooq J, Mahmood A, et al (2011) An overview of cotton leaf curl virus disease (CLCUD) a serious threat to cotton productivity. Aust J Crop Sci 5:1823-1831. doi: 10.1001/jama.287.9.1132

Farooq J, Farooq A, Riaz M, et al (2014) Cotton leaf curl virus disease a principle cause of decline in cotton productivity in Pakistan (a mini review). Can J Plant Prot 2:9-16. doi: $10.1108 / 17465729200500020$

Follett PA (2017) Insect-plant interactions: host selection, herbivory, and plant resistance an introduction. Entomol Exp Appl 162:1-3. doi: 10.1111/eea.12524

GoP (2010) Pakistan Economic Survey. Pakistan Econ Surv 2010-11 23-41. doi: $10.1038 / 479299$ e 
Hashmi JA, Zafar Y, Arshad M, et al (2011) Engineering cotton (Gossypium hirsutum L.) for resistance to cotton leaf curl disease using viral truncated AC1 DNA sequences. Virus Genes 42:286-296. doi: 10.1007/s11262-011-0569-9

Höck J, Meister G (2008) The Argonaute protein family. Genome Biol 9:. doi: $10.1186 / \mathrm{gb}-2008-9-2-210$

Hussain M, Mansoor S, Iram S, et al (2007) The Hypersensitive Response to Tomato leaf curl New Delhi virus Nuclear Shuttle Protein Is Inhibited by Transcriptional Activator Protein. Mol Plant-Microbe Interact 20:1581-1588. doi: 10.1094/MPMI-20-12-1581

Iqbal Z, Sattar MN, Shafiq M (2016) CRISPR/Cas9: A Tool to Circumscribe Cotton Leaf Curl Disease. Front Plant Sci 7:1-11. doi: 10.3389/fpls.2016.00475

Jin B, Li Y, Robertson KD (2011) DNA methylation: Superior or subordinate in the epigenetic hierarchy? Genes and Cancer 2:607-617. doi: 10.1177/1947601910393957

Khan MAU, Shahid AA, Rao AQ, et al (2015) Defense strategies of cotton against whitefly transmitted CLCuV and Begomoviruses. Adv Life Sci 2:58-66. doi: 10.1111/j.1558-5646.2008.00432.x

Khatoon S, Kumar A, Sarin NB, Khan JA (2016) RNAi-mediated resistance against Cotton leaf curl disease in elite Indian cotton (Gossypium hirsutum) cultivar Narasimha. Virus Genes 52:530-537. doi: 10.1007/s11262-016-1328-8

Krupovic M, Cvirkaite-krupovic V (2011) Virophages or satellite viruses? Nat Rev Microbiol 9:762-763. doi: $10.1038 /$ nrmicro2676

Law JA, Jacobsen SE (2010) Establishing, maintaining and modifying DNA methylation patterns in plants and animals. Nat Rev Genet 11:204-220. doi: 10.1038/nrg2719

Liu YL, Robinson DJ, Harrison BD, Zhou XP (1998) Four DNA-A variants among Pakistani isolates of cotton leaf curl virus and their affinities to DNA-A of geminivirus isolates from okra. J Gen Virol 79:1501-1508

Lopez-Serra P, Esteller M (2012) DNA methylation-associated silencing of tumor-suppressor microRNAs in cancer. Oncogene 31:1609-22. doi: 10.1038/onc.2011.354

Malik HJ, Raza A, Amin I, et al (2016) RNAi-mediated mortality of the whitefly through transgenic expression of double-stranded RNA homologous to acetylcholinesterase and ecdysone receptor in tobacco plants. Sci Rep 6:1-11. doi: 10.1038/srep38469

Mansoor S, Amin I, Briddon RW (2008) Cotton leaf curl disease. Encycl Virol 563-569. doi: 10.1016/B978-012374410-4.00703-2 
Monga D, Chakrabarty PK, Kranthi KR (2011) Cotton leaf curl virus disease in India-Recent status and management strategies. Fifth Meet Asian Cott Res Dev network, Lahore 23-25

Mubin M, Amin I, Amrao L, et al (2010) The hypersensitive response induced by the V2 protein of a monopartite begomovirus is countered by the C2 protein. Mol Plant Pathol 11:245-254. doi: 10.1111/j.1364-3703.2009.00601.x

Pooggin M, Shivaprasad P V., Veluthambi K, Hohn T (2003) RNAi targeting of DNA virus in plants. Nat Biotechnol 21:131-132. doi: 10.1038/nbt0203-131b

Pooggin MM, Hohn T (2004) Fighting geminiviruses by RNAi and vice versa. Plant Mol Biol 55:149-152. doi: $10.1007 /$ s11103-004-0116-3

Pusch O, Boden D, Silbermann R, et al (2003) Nucleotide sequence homology requirements of HIV-1-specific short hairpin RNA. Nucleic Acids Res 31:6444-6449. doi: $10.1093 / \mathrm{nar} / \mathrm{gkg} 876$

Qazi J, Amin I, Mansoor S, et al (2007) Contribution of the satellite encoded gene $\beta C 1$ to cotton leaf curl disease symptoms. Virus Res 128:135-139. doi: $10.1016 / \mathrm{j}$.virusres.2007.04.002

Rahman M-, Khan AQ, Rahmat Z, et al (2017) Genetics and Genomics of Cotton Leaf Curl Disease, Its Viral Causal Agents and Whitefly Vector: A Way Forward to Sustain Cotton Fiber Security. Front Plant Sci 8:1-14. doi: 10.3389/fpls.2017.01157

Saeed M, Briddon R, Dalakouras A, et al (2015) Functional Analysis of Cotton Leaf Curl Kokhran Virus/Cotton Leaf Curl Multan Betasatellite RNA Silencing Suppressors. Biology (Basel) 4:697-714. doi: 10.3390/biology4040697

Saeed M, Zafar Y, Randles JW, Rezaian MA (2007) A monopartite begomovirus-associated DNA $\beta$ satellite substitutes for the DNA $B$ of a bipartite begomovirus to permit systemic infection. J Gen Virol 88:2881-2889. doi: 10.1099/vir.0.83049-0

Saleem H, Nahid N, Shakir S, et al (2016) Diversity, mutation and recombination analysis of cotton leaf curl geminiviruses. PLoS One 11:1-12. doi: 10.1371/journal.pone.0151161

Sattar MN, Kvarnheden A, Saeed M, Briddon RW (2013) Cotton leaf curl disease - An emerging threat to cotton production worldwide. J Gen Virol 94:695-710. doi: 10.1099/vir.0.049627-0

Saxena S, Tiwari AK (2017) Begomoviruses: Occurrence and management in Asia and Africa Schübeler D (2015) Function and information content of DNA methylation. Nature 517:321326. doi: $10.1038 /$ nature 14192 
Shepherd DN, Martin DP, Thomson JA (2009) Transgenic strategies for developing crops resistant to geminiviruses. Plant Sci 176:1-11. doi: 10.1016/j.plantsci.2008.08.011

Singh A (2014) Cotton Leaf Curl Virus Time Bomb

Smalling KL, Kuivila KM, Orlando JL, et al (2013) Environmental fate of fungicides and other current-use pesticides in a central California estuary. Mar Pollut Bull 73:144-153. doi: 10.1016/j.marpolbul.2013.05.028

Sun J, Yuan C (2017) Analyze and Compare the Function of Several Common Operators in Feature Extraction on Cotton Diseases. 75:467-470

Voinnet O. (2001) RNA silencing as a plant immune system against viruses. TRENDS Genet $17: 449-459$

Vyas M, Raza A, Ali MY, et al (2017) Knock down of whitefly gut gene expression and mortality by orally delivered gut gene-specific dsRNAs. PLoS One 12:1-19. doi: 10.1371/journal.pone.0168921

X W, Q Z, J L, et al (2012) Analysis of a native whitefly transcriptome and its sequence divergence with two invasive whitefly species. BMC Genomics 13:529

Zafar ZU, Athar HUR (2013) Reducing disease incidence of cotton leaf curl virus (CLCUV) in cotton (Gossypium Hirsutum L.) by potassium supplementation. Pakistan J Bot 45:10291038 